\title{
ANALISIS KESULITAN GURU BAHASA JEPANG DALAM MENGIMPLEMENTASIKAN PEMBELAJARAN BERDASARKAN KURIKULUM 2013 DI SMA DAN SMK SE-KABUPATEN TABANAN
}

\author{
P.U. Murtiningsih ${ }^{1}$ I.W. Sadyana ${ }^{2}$ K.E.K. Adnyani ${ }^{3}$ \\ ${ }^{123}$ Jurusan Pendidikan Bahasa Jepang, Universitas Pendidikan Ganesha, Singaraja,Bali \\ e-mail: : utariputu11@gmail.com \\ wayan.sadyana@undiksha.ac.id krishna.adnyani@undiksha.ac.id
}

\begin{abstract}
Abstrak
Penelitian ini bertujuan untuk (1) menganalisis tingkat kesulitan guru bahasa Jepang di SMA dan SMK se-Kabupaten Tabanan dalam mengimplementasikan pembelajaran berdasarkan Kurikulum 2013 pada tahap perencanaan, pelaksanaan, dan penilaian, (2) menganalisis kategori guru bahasa Jepang yang mengalami kesulitan lebih tinggi dalam mengimplementasikan pembelajaran berdasarkan Kurikulum 2013 pada tahap perencanaan, pelaksanaan, dan penilaian. Kategori tersebut meliputi status kepegawaian, latar belakang pendidikan, pelatihan Kurikulum 2013, status sekolah, dan jangka waktu mengimplementasikan Kurikulum 2013. Metode pengumpulan data yang digunakan adalah metode angket dan wawancara. Angket dianalisis menggunakan teknik analisis data kuantitatif, sedangkan data wawancara dianalisis dengan teknik analisis data kualitatif. Hasil penelitian ini yaitu (1) pada perencanaan $13,64 \%$ responden tergolong tidak sulit, $59,09 \%$ responden tergolong cukup sulit, dan $27,27 \%$ tergolong sulit, pada pelaksanaan $36,36 \%$ responden tergolong tidak sulit, $45,45 \%$ responden tergolong cukup sulit, dan $18,18 \%$ tergolong sulit, pada penilaian $50 \%$ responden tergolong tidak sulit, $27,27 \%$ tergolong cukup sulit, dan $22,73 \%$ tergolong sulit, (2) kategori guru yang mengalami kesulitan lebih tinggi yaitu guru non PNS, guru lulusan non kependidikan, guru yang belum pernah mengikuti pelatihan $\mathrm{K} 13$, dan guru yang mengajar di sekolah swasta. Guru yang menerapkan Kurikulum 2013 selama kurang dari 1 tahun mengalami kesulitan paling tinggi pada pelaksanaan dan penilaian. Tetapi pada perencanaan, guru yang menerapkan Kurikulum 2013 selama 1 tahun mengalami kesulitan tertinggi.
\end{abstract}

Kata kunci: kesulitan guru bahasa Jepang, implementasi, Kurikulum 2013

$$
\text { 要旨 }
$$

本研究では、（1）タバナン地区の高等学校 および専門学校の日本語教師が直面した 計画、実施、評価段階で2013年のカリキュラム実施困難分析することであり、(2) 計画、実施、評価段階で2013年のカリキュラム実施のもつと困難日本語教師のカテ ゴリを分析することである。そのカテゴリーは雇用状態、教育の背景、2013カリキ ユラムのトレーニング、学校の状態と2013カリキュラムを実施する時間である。調 查対象は、インタビュー、アンケートより収集したデータである。アンケートは定 量的記述法により分析して、インタビューデータは定性的記述法により分析した。 本研究の結果は、（1）計画段階では「困難ではない」が13.64\%、「かなり困難」 が59.09\%、「困難である」が27.27\% と回答された。実施段階では「困難ではな い」が36,36\%「かなり困難」が45,45\%、「困難である」が $27.27 \%$ と回答された。 評価段階では「困難ではない」が50\%、「かなり困難」が27,27\%、「困難である」 が 22,73\%と回答された。(2)非常勤教員、教員養成受けない教員、2013年のカリキ ユラムの研修を受けてない教員、私立学校の教員はもっと困難なことがある。2013 カリキュラムを 1 年未満で適用する教師は実施段階と評価段階では一番困難なことが ある。しかし、計画段階では2013年のカリキュラムを1年間適用する教師は一番困難 なことがある。

キーワード : 日本語教師の困難、実施、20 13 年のカリキュラム 


\section{Pendahuluan}

Sejak tahun 1947, Indonesia telah mengalami sepuluh kali perubahan kurikulum. Perubahan kurikulum dilakukan apabila kurikulum yang berlaku dipandang sudah tidak efektif dan tidak relevan lagi dengan perkembangan IImu Pengetahuan dan Teknologi (IPTEK), tuntutan zaman, dan kebutuhan masyarakat. Saat ini, di Indonesia diterapkan Kurikulum 2013 yang merupakan pengembangan dari dari Kurikulum Berbasis Kompetensi 2004 dan Kurikulum Tingkat Satuan Pendidikan 2006.

Kurikulum 2013 merupakan kurikulum berbasis kompetensi dan karakter. Tidak seperti kurikulum sebelumnya yang memfokuskan pada pengembangan kompetensi semata. Penerapan kurikulum berbasis kompetensi dan karakter diharapkan dapat membekali peserta didik dengan berbagai sikap dan keterampilan yang sesuai dengan tuntutan teknologi dan perkembangan zaman, sehingga dapat menghadapi persaingan global yang semakin ketat (Mulyasa, 2017).

Pelaksanaan Kurikulum 2013 mewajibkan pendidikan karakter diintegrasikan ke dalam kegiatan pembelajaran masing-masing bidang studi. Berdasarkan hal tersebut, tugas guru menjadi semakin berat karena pembelajaran tidak hanya menekankan pada kompetensi pengetahuan, melainkan juga pembentukan karakter peserta didik.

Dalam Permendikbud Nomor 22 Tahun 2016 tentang Standar Proses Pendidikan Dasar dan Pendidikan Menengah disebutkan bahwa proses pembelajaran terdiri atas kegiatan perencanaan, pelaksanaan, dan penilaian. Perencanaan, pelaksanaan, dan penilaian pembelajaran berdasarkan Kurikulum 2013 memiliki perbedaan dengan perencanaan, pelaksanaan, dan penilaian pembelajaran berdasarkan kurikulum sebelumnya.

Perencanaan pembelajaran berdasarkan Kurikulum 2013 disusun dalam bentuk silabus dan Rencana Pelaksanaan Pembelajaran (RPP). Silabus bersumber dari pemerintah, sehingga guru hanya mengembangkan RPP berdasarkan silabus yang diberikan. RPP dalam Kurikulum 2013 dirancang dengan mengintegrasikan pendidikan karakter, HOTS (Higher Order Thinking Skills), budaya literasi, dan keterampilan abad 21 (communication, collaboration, critical thinking and problem solving, creativity and innovation). Berdasarkan hal tersebut, tantangan yang dihadapi guru dalam menyusun perencanaan pembelajaran menjadi semakin kompleks.

Pelaksanaan pembelajaran berdasarkan Kurikulum 2013 dilakukan dengan menerapkan langkah-langkah pendekatan scientific yang terdiri atas mengamati, menanya, mencoba, menalar, dan mengomunikasikan. Penerapan pendekatan scientific menjadikan siswa sebagai pusat pembelajaran,sedangkan guru berperan sebagai fasilitator.

Penilaian pembelajaran berdasarkan Kurikulum 2013 menggunakan penilaian autentik yang menilai secara utuh proses dan hasil pembelajaran. Dalam penilaian autentik, guru tidak hanya menilai aspek pengetahuan, melainkan juga sikap dan keterampilan peserta didik. Dengan demikian, terdapat tambahan tugas bagi guru dalam melakukan penilaian karena kriteria penilaian pada Kurikulum 2013 lebih banyak, dibandingkan dengan penilaian konvensional.

Melihat banyaknya perubahan dari kurikulum sebelumnya, tentu terdapat kesulitan yang dialami oleh guru dalam mengimplementasikan pembelajaran berdasarkan Kurikulum 2013. Kurniasih dan Sani (2016) menyatakan bahwa salah satu permasalahan yang muncul di awal penerapan Kurikulum 2013 adalah ketidaksiapan guru dalam melaksanakan pembelajaran sesuai Kurikulum 2013. Berdasarkan sejumlah permasalahan yang terdapat pada satu tahun pertama penerapan Kurikulum 2013, pemerintah melakukan revisi kurikulum dengan mengganti ketentuan-ketentuan yang menyulitkan guru dalam mengimplementasikan Kurikulum 2013.

Meskipun pemerintah telah melakukan perubahan untuk mengganti sejumlah hal yang dianggap menyulitkan, namun tidak menutup kemungkinan bahwa terdapat kesulitan yang ditemui oleh guru dalam menerapkan Kurikulum 2013 pasca revisi. Terlebih lagi, saat ini seluruh sekolah telah dihimbau untuk menggunakan Kurikulum 2013, sehingga banyak guru 
yang baru saja mengimplementasikan pembelajaran berdasarkan Kurikulum 2013. Salah satunya adalah guru bahasa Jepang di SMA dan SMK yang terdapat di Kabupaten Tabanan, Bali.

Berdasarkan observasi awal, diketahui bahwa di Kabupaten Tabanan terdapat 14 SMA dan 14 SMK. Dari 28 SMA dan SMK, sebanyak 25 sekolah sudah menerapkan Kurikulum 2013. Dari 25 SMA dan SMK yang sudah menerapkan Kurikulum 2013, 16 sekolah memberikan mata pelajaran bahasa Jepang sebagai mata pelajaran bahasa asing selain bahasa Inggris. Sebagian besar SMA dan SMK di Kabupaten Tabanan memberikan pelajaran bahasa Jepang. Hal tersebut menunjukkan bahwa bahasa Jepang merupakan salah satu bahasa asing yang diminati pada jenjang SMA dan SMK. Terlebih lagi, di Kabupaten Tabanan terdapat beberapa daerah tujuan wisata yang banyak dikunjungi wisatawan seperti Tanah Lot, Jati Luwih, dan Kebun Raya Eka Karya Bedugul. Melihat potensi wisata yang terdapat di Kabupaten Tabanan, maka diperlukan pemberian pelajaran bahasa asing, seperti bahasa Jepang pada jenjang SMA dan SMK.

Pelaksanaan pembelajaran bahasa Jepang di SMA dan SMK se-Kabupaten Tabanan tentunya dipengaruhi Kurikulum yang diterapkan saat ini, yaitu Kurikulum 2013. Agar pembelajaran bahasa Jepang dapat dilaksanakan sesuai dengan Kurikulum 2013 diperlukan peran dan kompetensi guru bahasa Jepang dalam mengimplementasikan kurikulum ke dalam pembelajaran di kelas, karena guru memegang peran penting dalam keberhasilan penerapan kurikulum.

Melalui studi pendahuluan yang dilakukan dengan mewawancarai guru bahasa Jepang di SMA dan SMK di Kabupaten Tabanan, diperoleh informasi bahwa terdapat kesulitan yang dihadapi oleh guru bahasa Jepang dalam mengimplementasikan pembelajaran berdasarkan Kurikulum 2013. Kesulitan tersebut antara lain, sulit dalam merancang RPP, ketersediaan buku ajar yang terbatas, pembelajaran belum sepenuhnya tepusat pada siswa sehingga terkesan masih seperti KTSP, pendekatan scientific belum dapat dilaksanakan dengan maksimal, khususnya pada tahap menanya, dan kesulitan dalam melaksanakan penilaian, khususnya pada penilaian sikap.

Melalui wawancara tersebut diperoleh informasi bahwa kesulitan tidak hanya dialami oleh guru bahasa Jepang yang menerapkan Kurikulum 2013 selama kurang dari satu tahun, tetapi juga oleh guru yang sudah menerapakan selama beberapa tahun. Kesulitan dalam mengimplementasikan Kurikulum 2013 juga diungkapkan oleh guru bahasa Jepang yang sudah pernah dan belum pernah mengikuti pelatihan Kurikulum 2013, guru bahasa Jepang dengan status PNS dan non PNS, serta guru yang mengajar di sekolah negeri maupun swasta.

Berdasarkan uraian di atas, diperlukan penelitian yang menganalisis kesulitan guru bahasa Jepang dalam mengimplementasikan pembelajaran berdasarkan Kurikulum 2013 di SMA dan SMK se-Kabupaten Tabanan. Implementasi Kurikulum 2013 merupakan topik yang menarik untuk diteliti. Karena saat ini Kurikulum 2013 sedang diterapkan pada jenjang pendidikan dasar dan pendidikan menengah. Berbagai temuan yang dihasilkan melalui penelitian yang dilaksanakan dapat menjadi masukan dan pertimbangan bagi pemerintah dalam melaksanakan evaluasi Kurikulum 2013 yang berdampak pada peningkatan kualitas pendidikan.

Dari latar belakang yang telah dipaparkan, dapat dirumuskan permasalahan adalah sebagai berikut.

1. Bagaimana tingkat kesulitan guru bahasa Jepang di SMA/SMK se-Kabupaten Tabanan dalam mengimplementasikan pembelajaran berdasarkan berdasarkan Kurikulum 2013 pada tahap perencanaan pembelajaran, pelaksanaan, dan penilaian?

2. Kategori guru guru yang bagaimana membuat kesulitan lebih tinggi dalam mengimplementasikan pembelajaran bahasa Jepang berdasarkan Kurikulum 2013 pada tahap perencanaan pembelajaran, pelaksanaan, dan penilaian di SMA/SMK seKabupaten Tabanan?

\section{Kurikulum 2013}


Hamalik (2007) menyatakan bahwa kurikulum merupakan suatu program kegiatan yang direncanakan untuk dialami seluruh siswa. Kurikulum merupakan gabungan dari mata pelajaran, teknik mengajar, rumusan tujuan pembelajaran, cara melakukan evaluasi, dan hal lain yang dapat direncanakan. Pada hakikatnya, kurikulum merupakan suatu program terencana yang mencakup berbagai hal dalam pembelajaran

Kurikulum 2013 merupakan kurikulum berbasis kompetensi sekaligus berbasis karakter (competency and character based curriculum). Kurikulum berbasis kompetensi menekankan pada pemerolehan dan pengembangan kompetensi (pengetahuan, sikap, dan keterampilan) peserta didik, sedangkan pendidikan karakter diintegrasikan dalam seluruh pembelajaran bertujuan untuk meningkatkan mutu proses dan hasil pendidikan. Melalui penerapan kurikulum berbasis kompetensi dan karakter diharapakan dapat membentuk SDM yang berbudi pekerti luhur serta dilengkapi dengan berbagai keahlian yang sesuai dengan perkembangan zaman dan teknologi (Mulyasa, 2017).

\section{Perencanaan Pembelajaran}

Dalam Permendikbud Nomor 22 Tahun 2016 tentang Standar Proses Pendidikan Dasar dan Menengah disebutkan bahwa perencanaan pembelajaran dirancang dalam bentuk silabus dan Rencana Pelaksanaan Pembelajaran (RPP). Penyusunan silabus dan RPP disesuaikan dengan pendekatan pembelajaran yang digunakan. Mulyasa (2017) menambahkan bahwa dalam Kurikulum 2013, silabus masing-masing mata pelajaran telah disiapkan oleh pemerintah, sehingga guru hanya perlu mengembangkan rencana pembelajaran.

\section{Pelaksanaan Pembelajaran}

Pelaksanaan pembelajaran berdasarkan Kurikulum 2013 menggunakan pendekatan scientific, yaitu pembelajaran dipandang sebagai suatu proses ilmiah. Pendekatan scientific dimaksudkan untuk memberi pemahaman terhadap peserta didik untuk mengetahui, memahami, dan mempraktikkan hal yang dipelajari secara ilmiah melalui kegiatan mengamati, menanya, mencoba, mengolah informasi, dan menyajikan (Musfiqon dan Nurdyansyah, 2015).

Sumayasa (2015) menambahkan bahwa pendekatan scientific melatih peserta didik untuk mencari informasi dari mana saja, sehingga tidak bergantung pada informasi searah dari guru. Peserta didik dituntut aktif untuk menggunakan berbagai sumber belajar agar dapat menemukan informasi yang diperlukan secara mandiri. Pembelajaran dengan pendekatan scientific merupakan pembelajaran yang berpusat pada peserta, sedangkan guru hanya berperan sebagai fasilitator yang bertugas mengonfirmasi jika informasi yang ditemukan oleh peserta didik sudah tepat atau sebaliknya.

Dalam Peraturan Menteri Pendidikan dan Kebudayaan Nomor 22 Tahun 2016 tentang Standar Proses Pendidikan Dasar dan Menengah disebutkan bahwa penerapan pendekatan scientific didukung dengan penerapan model pembelajaran yang disesuaikan dengan karakteristik peserta didik dan mata pelajaran. Model pembelajaran yang digunakan untuk memperkuat pendekatan scientific, yaitu model Inquiry, Discovery, Problem Based Learning, dan Project Based Learning.

\section{Penilaian Pembelajaran}

Penilaian yang digunakan dalam Kurikulum 2013 adalah penilaian autentik, yaitu bentuk penilaian yang menilai kesiapan peserta didik, proses, dan hasil belajar secara utuh. Dalam Permendikbud Nomor 22 Tahun 2016 tentang Standar Proses Pendidikan Dasar dan Menengah disebutkan bahwa hasil penilaian autentik digunakan oleh guru untuk melakukan tindakan remedial, pengayaan, dan pelayanaan konseling. Selain itu, hasil penilaian autentik juga digunakan sebagai bahan untuk memperbaiki proses pembelajaran sesuai dengan Standar Penilaian Pendidikan.

\section{Metode}




\section{Metode Pengumpulan Data}

Metode yang digunakan untuk mengumpulkan data dalam penelitian ini, yaitu angket dan wawancara. Angket yang digunakan merupakan angket tertutup, berisi 34 butir pertanyaan disertai dengan 4 alternatif jawaban, yaitu sangat sulit (SS) dengan skor 4, sulit (S) dengan skor 3, cukup sulit (CS) dengan skor 2, dan tidak sulit (TS) dengan skor 1. Metode angket digunakan untuk memperoleh data tingkat kesulitan guru dalam mengimplementasika pembelajaran berdasarkan Kurikulum 2013.

Wawancara dilakukan untuk mendapatkan data yang mendukung hasil angket yang telah diisi oleh responden. Wawancara yang digunakan dalam penelitian ini adalah semi terstruktur.

Sumber data dalam penelitian ini yaitu guru bahasa Jepang di SMA dan SMK seKabupaten Tabanan yang berjumlah 22 orang.

\section{Metode dan Teknik Analisis Data}

Teknik analisis data dalam penelitian ini dibedakan menjadi dua, yaitu teknik analisis data kuantitatif dan kualitatif. Teknik analisis data kuantitatif digunakan untuk menganalisis data hasil pengisian angket, sedangkan teknik analisis data kualitatif digunakan untuk menganalisis data hasil wawancara.

Teknik analisis data kualitatif terdiri atas beberapa tahapan, yaitu (1) pencatatan dan penjumlahan skor angket masing-masing responden, (2) data diolah menggunakan distribusi frekuensi dengan pendekatan Sturges, (3) data dikategorikan ke dalam empat kategori, yaitu sangat sulit (SS); sulit (S); cukup sulit (CS); dan tidak sulit (TS). Untuk memperoleh frekuensi interval masing-masing kategori digunakan rumus sebagai berikut.

$$
\begin{aligned}
& \text { Interval }=\frac{\text { range }}{\text { kategori }} \\
& \text { Interval }=\frac{4-1}{4} \\
& \text { Interval }=0,75
\end{aligned}
$$

Keterangan:

Interval : jarak antara batas atas dan batas bawah kelas

Range : skor maksimum - skor minimum

Kategori : jumlah kategori yang digunakan

(Mustafa, 2009)

Setelah dikelompokkan ke dalam empat kategori, data diinterpretasikan ke dalam bentuk persentase dengan rumus sebagai berikut.

$$
P=\frac{f}{N} X 100 \%
$$

Keterangan:

$P$ : Angka persentase yang dicari

$\mathrm{F}$ : Frekuensi jawaban

$\mathrm{N}$ : Jumlah frekuensi/banyaknya data individu(Sudijono, 2008).

Untuk mengetahui hubungan antara kategori guru (status kepegawaian, latar belakang pendidikan, pernah tidaknya mengikuti pelatihan Kurikulum 2013, status sekolah tempat 
mengajar, dan jangka waktu mengimplementasikan Kurikulum 2013) dengan tingkat kesulitan dilakukan tabulasi silang menggunakan bantuan aplikasi SPSS 16 for Windows.

Analisis data kualitatif dilakukan dengan beberapa tahapan yaitu (1) coding, yakni memberi kode terhadap data yang terkumpul, (2) data dikelompokkan menjadi data sejenis, dan (3) penarikan simpulan dengan melihat pendapat narasumber yang paling banyak muncul dalam poin yang ditanyakan. Data wawancara selanjutnya dipaparkan untuk mendukung hasil analisis data angket.

\section{Hasil dan Pembahasan}

\section{Hasil Penelitian}

Tahap Perencanaan

Tingkat kesulitan pada tahap perencanaan diukur dengan 13 butir pertanyaan, yaitu pertanyaan nomor 1 sampai 13 pada angket. maksimum yang diperoleh yaitu 38 , sedangkan skor minimum 16. Tingkat kecenderungan kesulitan pada tahap perencanaan dapat dilihat pada tabel 1.

Tabel 1. Kecenderungan Kesulitan Tahap Perencanaan

\begin{tabular}{clcrr}
\hline No & \multicolumn{1}{c}{ Kategori } & Interval & Frekuensi & Persentase \\
\hline 1 & TS (Tidak Sulit) & $1,00-1,74$ & 6 & $27,27 \%$ \\
\hline 2 & CS (Cukup Sulit) & $1,74-2,49$ & 13 & $59,09 \%$ \\
\hline 3 & S (Sulit) & $2,50-3,24$ & 3 & $13,64 \%$ \\
\hline 4 & SS (Sangat Sulit) & $3,25-4,00$ & 0 & $0,00 \%$ \\
\hline \multicolumn{2}{r}{ Jumlah } & & 22 & $100 \%$ \\
\hline \multicolumn{2}{r}{} \\
\hline
\end{tabular}

Berdasarkan data dalam tabel, dapat diketahui bahwa tingkat kesulitan guru bahasa Jepang dalam mengimplementasikan pembelajaran berdasarkan Kurikulum 2013 pada tahap perencanaan sebesar $27,27 \%$ responden tergolong dalam kategori tidak sulit $59,09 \%$ responden tergolong dalam kategori cukup sulit, dan 13,64\% responden tergolong dalam kategori sulit.

Hasil wawancara menyatakan bahwa dalam perencanaan guru bahasa Jepang mengalami kesulitan pada pemilihan model pembelajaran, sulit mengintegrasikan pendidikan karakter, HOTS (Higher Order Thinking Skills), literasi, dan Keterampilan Abad 21 (communication, collaboration, critical thinking and problem solving, creativity and innovation) pada langkah-langkah pembelajaran dan sulit pengembangan materi pelajaran.

\section{Tahap Pelaksanaan}

Tingkat kesulitan pada tahap pelaksanaan diukur dengan 12 butir pertanyaan, yaitu pertanyaan nomor 14-25 pada angket. Skor maksimum yang diperoleh adalah 36, sedangkan skor minimum 12. Data tingkat kecenderungan kesulitan pada tahap pelaksanaan dapat dilihat pada tabel 2 .

Tabel 2. Kecenderungan Kesulitan

Tahap Pelaksanaan

\begin{tabular}{clcrr}
\hline No & \multicolumn{1}{c}{ Kategori } & Interval & Frekuensi & $\begin{array}{c}\text { Persent } \\
\text { ase }\end{array}$ \\
\hline 1 & TS (Tidak Sulit) & $1,00-1,74$ & 8 & $36,36 \%$ \\
\hline 2 & CS (Cukup Sulit & $1,74-2,49$ & 10 & $45,45 \%$ \\
\hline 3 & S (Sulit) & $2,50-3,24$ & 4 & $18,18 \%$ \\
\hline \multirow{2}{*}{4 SS (Sangat } & $3,25-4,00$ & 0 & $0,00 \%$ \\
& & & & \\
\hline
\end{tabular}


Berdasarkan data dalam tabel dapat diketahui bahwa tingkat kesulitan guru bahasa Jepang dalam mengimplementasikan pembelajaran berdasarkan Kurikulum 2013 pada tahap pelaksanaan sebesar $36,36 \%$ responden tergolong dalam kategori tidak sulit $45,45 \%$ responden tergolong dalam kategori cukup sulit, dan 18,18\% responden tergolong dalam kategori sulit.

Hasil wawancara menyatakan bahwa dalam tahap pelaksanaan guru bahasa Jepang mengalami kesulitan dalam melaksanakan pembelajaran scientific pada kegiatan menanya, menalar, dan mencipta, kesulitan menerapkan model pembelajaran, dan kesulitan melaksanakan seluruh tahapan pembelajaran yang sudah tertulis di RPP karena keterbatasan waktu.

\section{Tahap Penilaian}

Tingkat kesulitan pada tahap penilaian diukur dengan 9 butir pertanyaan, yaitu pertanyaan nomor 26-34 pada angket. Skor maksimum yang diperoleh yaitu 27, sedangkan skor minimum 9. Hasil analisis data pada tahap penilaian dapat dilihat pada tabel 3.

Tabel 3. Kecenderungan Kesulitan Tahap Penilaian

\begin{tabular}{|c|c|c|c|c|c|}
\hline No & Kateqori & \multicolumn{2}{|c|}{ Interval } & Frekuensi & Persentase \\
\hline 1 & TS (Tidak Sulit) & $\begin{array}{l}1,00 \\
1,74\end{array}$ & - & 11 & $50,00 \%$ \\
\hline 2 & CS (Cukup Sulit) & $\begin{array}{l}1,74 \\
2,49\end{array}$ & - & 6 & $27,27 \%$ \\
\hline 3 & S (Sulit) & $\begin{array}{l}2,50 \\
3,24\end{array}$ & - & 5 & $22,73 \%$ \\
\hline 4 & SS (Sangat Sulit) & $\begin{array}{l}3,25 \\
4,00\end{array}$ & - & 0 & $0,00 \%$ \\
\hline & Jumlah & & & 22 & $100 \%$ \\
\hline
\end{tabular}


Berdasarkan data yang disajikan dalam tabel, dapat diketahui bahwa tingkat kesulitan guru bahasa Jepang dalam mengimplementasikan pembelajaran berdasarkan Kurikulum 2013 pada tahap penilaian sebesar 50\% responden tergolong ke dalam kategori tidak sulit, $27,27 \%$ responden tergolong dalam kategori cukup sulit, dan $22,73 \%$ responden tergolong dalam kategori sulit.

Berdasarkan hasil wawancara, guru bahasa Jepang mengalami kesulitan melaksanakan penilaian autentik karena jenis penilaian yang dilakukan lebih kompleks daripada penilaian konvensional.

\section{Hubungan antara Kategori Guru dengan Tingkat Kesulitan}

Kategori guru yang dimaksud dilihat dari status kepegawaian (PNS dan Non PNS), latar belakang pendidikan (pendidikan dan non kependidikan), pernah tidaknya mengikuti pelatihan Kurikulum 2013, status sekolah tempat mengajar (negeri dan swasta), dan jangka waktu guru menggunakan Kurikulum 2013 dalam pembelajaran $(<1$ tahun, 1 tahun, $>1$ tahun).

\section{Status Kepegawaian}

Dari 22 responden, 4 responden berstatus sebagai guru PNS, sedangkan 18 responden berstatus sebagai guru non PNS. Hasil tabulasi silang antara kesulitan guru dengan status kepegawaian dapat dilihat pada gambar 1.

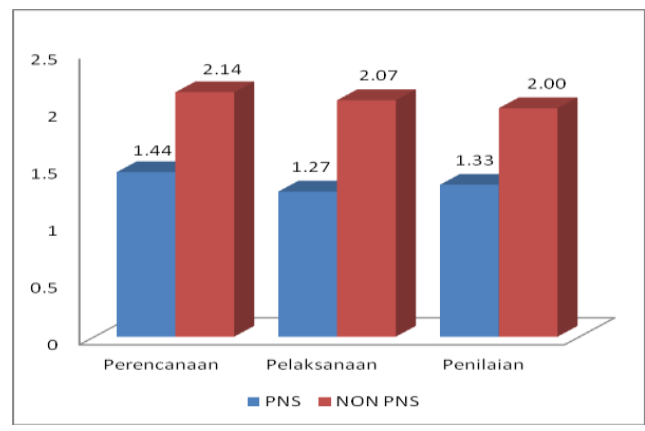

Gambar 1. Hubungan Tingkat Kesulitan dengan Status Kepegawaian

Pada gambar 1 dapat dicermati bahwa guru non PNS mengalami kesulitan lebih tinggi pada tahap perencanaan, pelaksanaan, dan penilaian dibandingkan dengan guru yang berstatus PNS. Guru non PNS mengalami kesulitan lebih tinggi karena guru non PNS lebih jarang mendapat pelatihan Kurikulum 2013 dibandingkan dengan guru PNS.

\section{Latar Belakang Pendidikan}

Dari 22 responden, 8 responden merupakan guru dengan latar belakang kependidikan, sedangkan 14 responden merupakan guru yang berlatar belakang non kependidikan. Hasil tabulasi silang antara kesulitan guru dengan latar belakang pendidikan dapat dilihat pada gambar 2 .

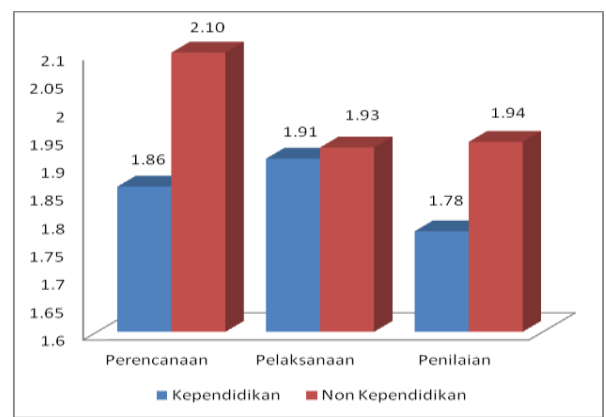

Gambar 2. Hubungan Tingkat Kesulitan dengan Latar Belakang Pendidikan 
Dari gambar 2 dapat diketahui bahwa, guru dengan latar belakang non kependidikan mengalami kesulitan lebih tinggi pada tahap perencanaan, pelaksanaan, dan penilaian dibandingkan dengan guru yang berlatar belakang kependidikan.

\section{Pelatihan Kurikulum 2013}

Dari 22 responden, sebanyak 15 responden sudah pernah mengikuti pelatihan Kurikulum 2013, sedangkan 7 orang responden lainnya dengan belum pernah mengikuti pelatihan. Hasil tabulasi silang antara kesulitan guru dengan keikutsertaan guru dalam pelatihan Kurikulum 2013 dapat dilihat pada gambar 3.

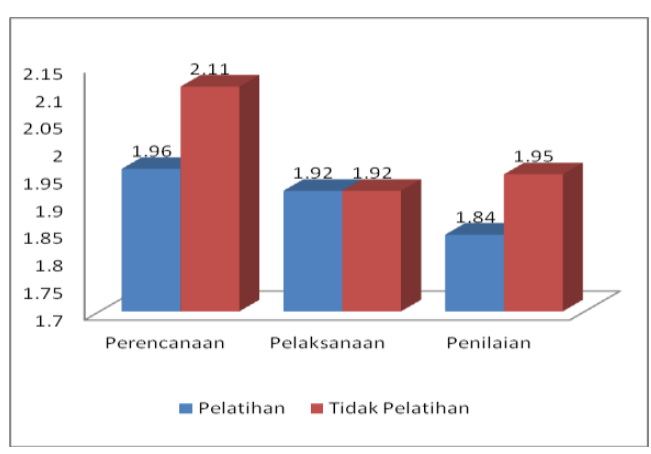

Gambar 3. Hubungan Tingkat Kesulitan dengan Pelatihan Kurikulum 2013

Berdasarkan gambar 3 diketahui bahwa pada tahap pelaksanaan, kesulitan antara guru yang sudah mengikuti pelatihan dengan guru yang belum mengikuti pelatihan sama besar, yaitu 1,92. Tetapi pada tahap perencanaan dan penilaian, guru yang belum pernah mengikuti pelatihan Kurikulum 2013 mengalami kesulitan lebih tinggi dibandingkan dengan guru yang sudah pernah mengikuti pelatihan.

\section{Status Sekolah}

Dari 22 responden, 11 responden merupakan guru yang mengajar di sekolah negeri, sedangkan 11 orang lainnya merupakan guru di sekolah swasta. Hasil tabulasi silang antara kesulitan guru dengan status sekolah tempat mengajar dapat dilihat pada gambar 4 .

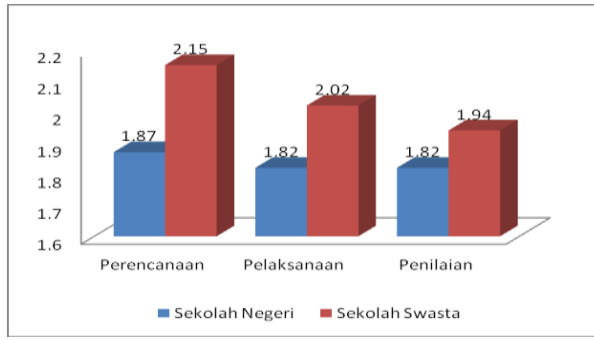

Gambar 4. Hubungan Tingkat Kesulitan dengan Status Sekolah

Berdasarkan gambar 4 dapat dilihat perbedaan tingkat kesulitan antara guru yang mengajar di sekolah negeri dan sekolah swasta. Guru yang mengajar di sekolah swasta mengalami kesulitan yang lebih tinggi dalam menerapkan pembelajaran berdasarkan Kurikulum 2013 di ketiga tahap pembelajaran, yaitu perencanaan, pelaksanaan, dan penilaian dibandingkan dengan guru di sekolah negeri.

\section{Jangka Waktu Implementasi Kurikulum 2013}

Dari 22 orang responden, sebanyak 11 responden mengimplementasikan Kurikulum 2013 selama $<1$ tahun, 7 orang responden mengimplementasikan Kurikulum 2013 selama 1 tahun, dan 4 orang responden dengan persentase mengimplementasikan Kurikulum 2013 
selama $>1$ tahun. Hasil tabulasi silang antara lama guru mengimplementasikan Kurikulum 2013 dengan tingkat kesulitan guru dapat dilihat pada gambar 5 .

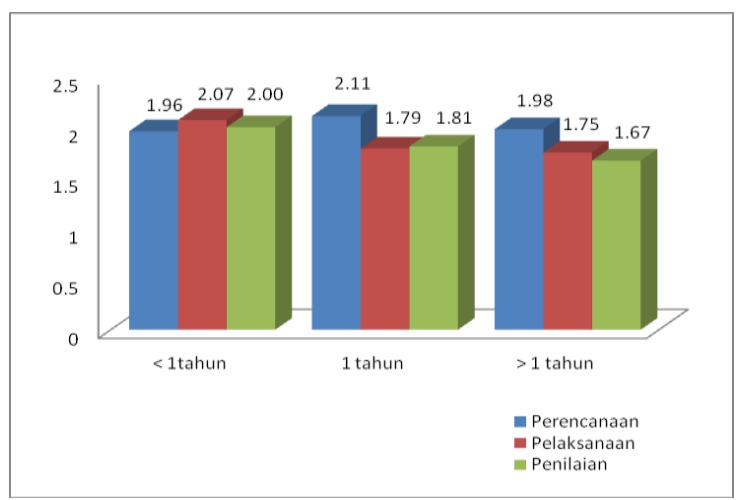

Gambar 5. Hubungan Tingkat Kesulitan dengan Lama Implementasi K13

Berdasarkan gambar 5 dapat diketahui bahwa pada tahap perencanaan guru yang mengalami kesulitan tertinggi yaitu guru yang mengimplementasikan Kurikulum 2013 selama 1 tahun, sedangkan guru yang mengimplementasikan $<1$ tahun mengalami kesulitan terendah.

Pada tahap pelaksanaan dan penilaian, kesulitan tertinggi dialami oleh guru yang mengimplementasikan Kurikulum 2013 selama $<1$ tahun, kemudian kesulitan lebih rendah dialami oleh guru yang mengimplementasikan Kurikulum 2013 selama 1 tahun, dan kesulitan terendah dialami oleh guru yang mengimplementasikan Kurikulum 2013 selama >1.

\section{PEMBAHASAN}

\section{Kesulitan pada Tahap Perencanaan}

Kesulitan yang dialami oleh guru bahasa Jepang pada perencanaan pembelajaran yaitu sulit dalam menentukan model pembelajaran, sulit mengintegrasikan pendidikan karakter, HOTS (Higher Order Thinking Skills), Literasi, dan Keterampilan Abad 21 (communication, collaboration, critical thinking and problem solving, creativity and innovation) pada langkah-langkah pembelajaran, sulit dan mengembangkan materi pelajaran.

Model pembelajaran yang digunakan pada Kurikulum 2013 yaitu model Inquiry, Discovery, Problem Based Learning, dan Project Based Learning. Model pembelajaran tersebut merupakan model pembelajaran yang menuntut siswa aktif dalam pembelajaran. Tetapi pada kondisi di lapangan, guru menemui karakteristik siswa yang kurang aktif. Situasi yang dihadapi oleh guru sangat berbeda dengan karakteristik Kurikulum 2013 yang menghendaki pembelajaran berpusat pada siswa. Oleh karena itu guru bahasa Jepang cukup sulit menentukan model pembelajaran yang akan digunakan.

Kesulitan berikutnya yang dihadapi oleh guru bahasa Jepang yaitu pendidikan karakter, HOTS (Higher Order Thinking Skill), Literasi, dan Keterampilan Abad 21 (communication, collaboration, critical thinking and problem solving, creativity and innovation) pada langkah-langkah pembelajaran. Hal tersebut merupakan hasil dari pelatihan Kurikulum 2013 terbaru. Dari 22 orang guru bahasa Jepang, hanya sebagian kecil yang sudah pernah mengikuti pelatihan Kurikulum 2013 terbaru, sehingga wajar terdapat kesulitan yang dialami oleh guru bahasa Jepang.

Kesulitan lain yang dihadapi oleh guru bahasa Jepang yaitu mengembangkan materi pelajaran. Kesulitan ini dihadapi oleh guru bahasa Jepang di SMK. Sampai saat ini, belum tersedian buku pelajaran bahasa Jepang khusus untuk SMK, sehingga guru mengembangkan materi pelajaran sesuai dengan kebutuhan siswa melalui modul yang disusun oleh guru di sekolah yang bersangkutan.

\section{Kesulitan pada Tahap Pelaksanaan}


Pada tahap pelaksanaan guru bahasa Jepang mengalami kesulitan dalam melaksanakan pembelajaran scientific pada kegiatan menanya, menalar, dan mencipta, kesulitan menerapkan model pembelajaran, dan kesulitan melaksanakan seluruh tahapan pembelajaran yang sudah tertulis di RPP karena keterbatasan waktu.

Kesulitan pada kegiatan menanya dan menalar disebabkan oleh siswa yang belum terbiasa mengkuti pembelajaran dengan pendekatan scientific, sehingga guru lebih sering memberikan stimulus agar tahap menanya dan menalar dapat tercapai. Sedangkan guru merasa kesulitan pada kegiatan mencipta karena hanya dapat mengarahkan peserta didik untuk menghasilkan karya yang sederhana berdasarkan contoh yang sudah ada.

Kesulitan dalam menerapkan model pembelajaran disebabkan oleh karakteristik kelas yang kurang aktif, sedangkan model pembelajaran berdasarkan Kurikulum 2013 menghendaki siswa untuk aktif dan menjadi pusat pembelajaran. Oleh karena itu, penerapan model pembelajaran menjadi kurang maksimal.

Keseluruhan kegiatan pembelajaran yang dirancang pada RPP juga tidak dapat terlaksana karena keterbatasan waktu. Pada tahap penyusunan rencana pembelajaran, guru sudah mengalokasikan waktu untuk masing-masing kegiatan. Tapi, dalam pelaksanaan di dalam kelas terdapat kendala seperti siswa yang menggangu jalannya pembelajaran ataupun siswa kesulitan dalam memahami materi pelajaran yang dibahas. Oleh karena itu, pelaksanaan pembelajaran tidak berlangsung sesuai dengan waktu yang dialokasikan pada RPP.

\section{Kesulitan pada Tahap Penilaian}

Penilaian pembelajaran berdasarkan Kurikulum 2013 menggunakan penilaian autentik yaitu penilaian yang menilai proses dan hasil belajar secara utuh. Penilaian autentik tidak hanya menilai aspek pengetahuan, melainkan juga aspek sikap dan keterampilan. Pada penilaian sikap guru menemui kendala yaitu belum dapat melakukan penilaian yang mendetail karena jumlah siswa yang tidak sedikit. Kriteria penilaian yang lebih kompleks daripada penilaian konvensional juga menjadi penyebab kesulitan guru dalam melakukan penilaian pembelajaran berdasarkan Kurikulum 2013.

\section{Hubungan Tingkat Kesulitan dengan Status Kepegawaian}

Guru bahasa Jepang dengan status non PNS mengalami kesulitan lebih tinggi dalam mengimplementasikan pembelajaran berdasarkan Kurikulum 2013 dibandingkan dengan guru bahasa Jepang yang berstatus PNS. Guru non PNS mengalami kesulitan lebih tinggi karena guru non PNS lebih jarang mendapat pelatihan Kurikulum 2013 dibandingkan dengan guru PNS.

Materi yang diberikan dalam pelatihan Kurikulum 2013 dapat membantu guru dalam melaksanakan kegiatan pembelajaran. Semakin sering guru mengikuti pelatihan, tentu semakin banyak informasi yang diperoleh. Sehingga guru dapat mengimplementasikan Kurikulum 2013 dengan lebih baik. Guru yang jarang mengikuti pelatihan tentu kurang mengetahui materi terbaru mengenai Kurikulum 2013. Hal tersebut menyebabkan guru mengalami kesulitan dalam mengimplementasikan Kurikulum 2013.

\section{Hubungan Tingkat Kesulitan dengan Latar Belakang Pendidikan}

Guru yang merupakan lulusan non kependidikan mengalami kesulitan lebih besar dalam mengimplementasikan pembelajaran bahasa Jepang berdasarkan Kurikulum 2013, dibanding dengan guru yang merupakan lulusan kependidikan. Kesulitan lebih tinggi yang dialami oleh guru dengan latarbelakang non kependidikan merupakan hal yang wajar. Karena guru lulusan non kependidikan mendapatkan materi tentang implementasi kurikulum melalui pelatihan dan workshop, berbeda dengan guru lulusan kependidikan yang mendapatkan materi tentang kurikulum dan pembelajaran melalui perkuliahan. 


\section{Hubungan Tingkat Kesulitan dengan Pelatihan Kurikulum 2013}

Guru yang belum pernah mengikuti Pelatihan kurikulum 2013 mengalami kesulitan lebih tinggi pada tahap perencanaan dan penilaian. Sedangkan pada tahap pelaksanaan, kesulitan yang dialami oleh guru yang sudah dan yang belum pelatihan sama besar.

Pelatihan sangat membantu guru dalam mengimplementasikan pembelajaran berdasarkan Kurikulum 2013. Hal tersebut ditunjukkan dengan perolehan rata-rata skor kesulitan lebih rendah pada guru yang sudah mengikuti pelatihan. Khususnya dalam perencanaan dan penilaian pembelajaran.

Keberhasilan perencanaan dan penilaian ditentukan oleh kemampuan guru dalam mengembangkan RPP serta teknik dan instrumen penilaian yang tepat. Sedangkan keberhasilan tahap pelaksanaan tidak hanya ditentukan oleh kemampuan guru dalam mengelola pembelajaran, tetapi juga ditentukan oleh keterlibatan siswa.

\section{Hubungan Tingkat Kesulitan dengan Status Sekolah}

Kesulitan lebih tinggi dalam mengimplementasikan pembelajaran berdasarkan Kurikulum 2013 dialami oleh guru-guru bahasa Jepang yang mengajar di sekolah swasta daripada di sekolah negeri. Dari 22 guru, 11 guru merupakan guru yang mengajar di sekolah negeri dan 11 lainnya merupakan guru di sekolah swasta.

Kesulitan yang dihadapi oleh guru di sekolah swasta juga dipengaruhi oleh pelatihan Kurikulum 2013 yang diikuti oleh guru. Dari 11 guru yang mengajar di sekolah swasta, 6 diantaranya belum pernah mengikuti pelatihan Kurikulum 2013. Berbeda dengan guru di sekolah negeri, dari 11 guru hanya 1 guru yang belum mengikuti pelatihan. Berdasarkan hal tersebut, dapat diketahui bahwa guru di sekolah negeri lebih banyak mendapatkan pelatihan Kurikulum 2013, dibanding dengan guru di sekolah swasta.

\section{Hubungan Tingkat Kesulitan dengan Jangka Waktu Implementasi Kurikulum 2013}

Pada tahap pelaksanaan dan penilaian, kesulitan tertinggi dialami oleh guru dengan lama implementasi Kurikulum $2013<1$ tahun, diikuti oleh kategori guru dengan lama implementasi 1 tahun, dan kesulitan terendah dialami oleh guru dengan kategori lama implementasi $>1$ tahun. Tetapi pada tahap perencanaan, kesulitan tertinggi dialami oleh guru yang mengimplementasikan Kurikulum 2013 selama 1 tahun, sedangkan kesulitan terendah dialami oleh guru yang mengimplementasikan Kurikulum 2013 selama $<1$ tahun.

Melalui wawancara diketahui bahwa guru bahasa Jepang yang sudah menerapkan Kurikulum 2013 selama satu tahun dan $>1$ tahun lebih mengalami kesulitan dalam merancang kegiatan pembelajaran dan memilih model pembelajaran. Guru merancang dan menggunakan model pembelajaran yan bervariasi agar siswa tidak mudah jenuh.

Sedangkan guru bahasa Jepang yang mengimplementasikan Kurikulum 2013 selama kurang dari satu tahun masih mencoba menerapkan model pembelajaran Kurikulum 2013 yang sesuai dengan karakteristik siswa. Guru belum terlalu banyak berinovasi dalam merancang pembelajaran karena model pembelajaran belum dapat diterapkan secara optimal. Siswa belum terbiasa dengan pembelajaran yang menjadikan siswa sebagai pusat, sedangkan guru berperan sebagai fasilitator.

\section{Simpulan dan Saran}

Kesulitan guru bahasa Jepang di SMA dan SMK se-Kabupaten Tabanan dalam mengimplementasikan pembelajaran berdasarkan Kurikulum 2013 pada tahap perencanaan sebesar 59\% tergolong cukup sulit, 27,27\% tergolong sulit, dan 13,64\% tergolong tidak sulit. Pada tahap pelaksanaan sebesar $45,45 \%$ responden berada pada kategori cukup sulit, $18,18 \%$ pada kategori sulit, dan $36,36 \%$ lainnya tergolong tidak sulit. Pada tahap penilaian sebesar $50 \%$ responden menyatakan tidak sulit, $27,27 \%$ menyatakan cukup sulit, dan $22,73 \%$ menyatakan sulit. 
Kategori guru yang lebih mengalami kesulitan dalam mengimplementasikan pembelajaran berdasarkan kurikulum 2013 yaitu (1) guru dengan status kepegawaian non PNS mengalami kesulitan lebih tinggi daripada guru PNS; (2) guru yang merupakan lulusan non kependidikan mengalami kesulitan lebih tinggi daripada guru lulusan kependidikan; (3) guru yang belum mengikuti pelatihan Kurikulum 2013 mengalami kesulitan lebih tinggi dibandingkan dengan guru yang sudah mengikuti pelatihan; (4) guru yang mengajar di sekolah swasta mengalami kesulitan lebih tinggi daripada guru di sekolah negeri; (5) Guru yang menerapkan Kurikulum 2013 selama $<1$ tahun mengalami kesulitan lebih tinggi pada tahap pelaksanaan dan penilaian, dibandingkan dengan guru yang sudah menerapkan Kurikulum 2013 selama 1 tahun dan $>1$ tahun. Tetapi pada tahap perencanaan, guru yang menerapkan Kurikulum 2013 selama <1 tahun mengalami kesulitan paling rendah, sedangkan guru yang menerapkan Kurikulum 2013 selama 1 tahun mengalami kesulitan tertinggi.

Berdasarkan temuan yang diperoleh dalam penelitian ini, pemerintah hendaknya mengadakan pelatihan Kurikulum 2013, khususnya bagi guru-guru di sekolah yang menerapkan Kurikulum 2013 selama $<1$ tahun. Pelatihan yang diselenggarakan sebaiknya merata antara guru di sekolah negeri maupun swasta, sekolah yang berada dekat maupun jauh dari pusat kota, agar Kurikulum 2013 diterapkan dan dilaksanakan dengan baik.

\section{Daftar Pustaka}

Hamalik, Oemar. 2007. Dasar- Dasar Pengembangan Kurikulum. Bandung: PT Remaja Rosdakarya Offset.

Kurniasih, Imas dan Sani, Berlin. 2016. Revisi Kurikulum 2013. Jakarta: Kata Pena.

Mulyasa, E. 2017. Pengembangan dan Implementasi Kurikulum 2013. Bandung: PT Remaja Rosdakarya Offset.

Musfiqon dan Nurdyansyah. 2015. Pendekatan Pembelajaran Saintifik. Sidoarjo: Nizamia Learning Center.

Mustafa, Zainal. 2009. Mengurai Variabel Hingga Instrumentasi. Yogyakarta: Graha Ilmu.

Permendikbud. 2016. Peraturan Menteri Pendidikan dan Kebudayaan Republik Indonesia Nomor 22 Tahun 2016 tentang Standar Proses Pendidikan Dasar dan Menengah.

Sudijono, Anas. 2008. Pengantar Statistik Pendidikan. Jakarta: PT Raja Grafindo Persada.

Sumayasa, I Nyoman. 2015. "Pengaruh Implementasi Pendekatan Saintifik terhadap Motivasi Belajar dan Hasil Belajar Bahasa Indonesia pada Siswa Kelas VI di Sekolah Dasar se-Gugus VI Kecamatan Abang, Karangsem”. E-Journal Program Pascasarjana Universitas Pendidikan Ganesha Program Studi Pendidikan Dasar, Volume 5 